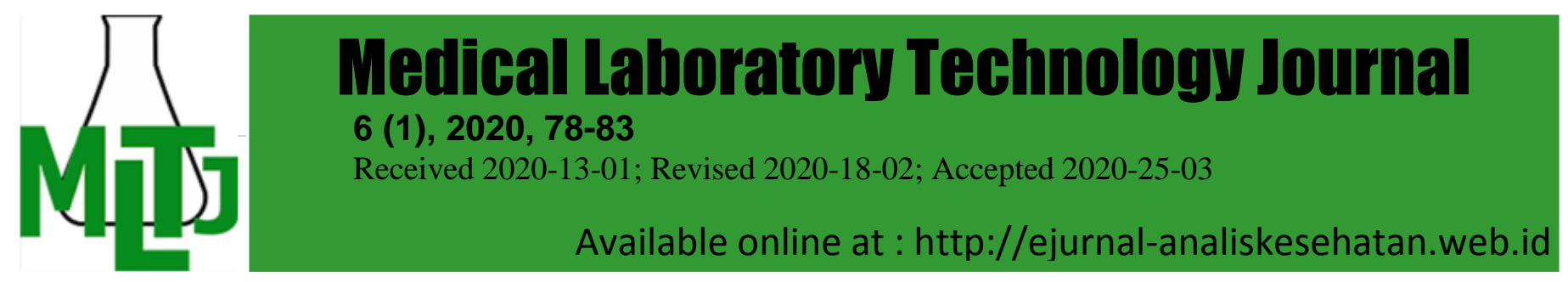

\title{
Hemoglobin Levels on Trichuris trichiura Infection in Children
}

\author{
*Ni Putu Aryadnyani, Dewi Inderiati, Fauzia Ulfah
}

\author{
Department of Medical Technology Laboratory Polytechnic of Health, \\ Ministry of Health, Jakarta III. Indonesia. \\ *Email: aryadnyani85@gmail.com \\ DOI: 10.31964/mltj.v1i1.289
}

\begin{abstract}
Worm infections often caused by worms transmitted through the soil (SoilTransmitted Helminths). Types of STH worms include roundworms (Ascaris lumbricoides), whipworms (Trichuris trichiura) and hookworms (Ancylostoma duodenale and Necator Americanus). Worms commonly suffered by school-age children with the most aged between 5-14 years. Worms can affect the intake, digestion, absorption, and metabolism of food, which can result in loss of protein, carbohydrates, fats, and vitamins. Trichuris trichiura and hookworm can cause massive amounts of blood loss and decreased hemoglobin levels. This study aims to determine the relationship of Trichuris trichiura infection with hemoglobin levels in children in the village of East Serang Kilasah, Banten. This research is an analytic survey with a cross-sectional design with 42 respondents. The sampling technique used was purposive sampling. The results of the fecal examination by the Kato-Katz method found 23 children (54.76\%) with mild worm levels and 19 children $(45.24 \%)$ with moderate worm levels. The results of blood tests found 36 children $(85.71 \%)$ with normal hemoglobin levels and six children (14.79\%) with low hemoglobin levels. Based on the results of statistical tests, the results obtained P-value 0.004 (P-value $<0.05)$. This result means that there is a significant relationship between Trichuris trichiura infection and hemoglobin levels in children in the Kilasah Serang Timur village of Banten. Efforts should be made from the local health office to increase knowledge about personal hygiene to villagers through health education to prevent helminth infections and to administer mass worm medicines every six months. It is also necessary to administer blood enhancing drugs for anemic citizens.
\end{abstract}

Keywords: worm Infection; haemoglobin; Soil-Transmitted Helminth

\section{INTRODUCTION}

Worm infections widely occur in rural and urban areas, high infection rates but different intensities of infections (Chadijah et al., 2014). Soil-Transmitted Helminth (STH) worm infection is a global problem, especially in developing countries (Basalamah et al., 2013). Around 2 billion people worldwide infected with worms, and 300 million of them suffer from severe infections, with 150 thousand deaths each year (Chadijah et al., 2014 and WHO, 2017).

Globally, an estimated 820 million people infected with Ascaris lumbricoides, 460 million are infected with Trichuris trichiura, and 440 million infected with hookworms. The infection is widespread in all regions, with the most significant number in sub-Saharan Africa, America, and Asia (WHO, 2017).

Indonesia is a country that has a tropical climate, so that the prevalence of worm infections is very high. Poor people have a high risk of getting infected with STH. The percentage of helminthiasis in Indonesia is $45-65 \%$. The prevalence can reach $80 \%$ in areas with poor sanitation (Inayah et al., 2016; Syahrir et al., 2016). 
Worm infections suffered by many elementary school-age children (Inayah et al., 2016). The results of helminthiasis in primary school showed a prevalence of around $60 \%-80 \%$, while for all ages ranged from $40 \%-60 \%$ (Inayah et al., 2016; Umar, 2008). The age group with the highest helminthiasis is 5-14 years because they have not been able to maintain personal hygiene (Basalamah et al., 2013; Ibrahim, 2014). Worm infections in children are also caused by frequent playing barefoot so that they contact with soil contaminated with hookworm larvae, Ascaris lumbricoides worm eggs, and Trichuris trichiura worm eggs due to the disposal of feces in any place (Semuel et al., 2015).

Worm infections affect intake, digestive, absorption, and food metabolism. This causes loss of protein, carbohydrates, fats, vitamins, and blood in large quantities and reduces the concentration of hemoglobin (Inayah et al., 2016; Directorate-General of P2PL, 2012; Rusmanto et al., 2012). Worm infections can also cause various symptoms of diseases such as diarrhea, dysentery syndrome, anemia, malnutrition and intelligence decreases (Basalamah et al., 2013 and Indriyati, L., et al., 2015).

The results of studies in Kupang in 2016 by Zuhaifah Inayah M.S, et al. showed that children infected with worms affected their hemoglobin levels. Children infected with worms had lower hemoglobin levels when compared to children not infected with worms (Basalamah et al., 2013; Inayah et al., 2016). However, the research by Basalamah et al. (2013) and Inayah et al. (2016) did not explain the type of worm that infects respondents. In this study, using respondents who were infected by Trichuris trichiura because types of worms that cause anemia are hookworms and whipworms (Trichuris trichiura). Ascaris lumbricoides worm infection does not cause anemia, but in severe infections causes malnutrition (Meru, 2006).

Kilasah Village is one of the ten villages in the Kasemen Banten sub-district. Most residents living in the village of Kilasah lack knowledge of personal hygiene, so they do not have a private toilet. For bathing, washing clothes, washing dishes, cooking, and other daily needs, they use river water and ponds. Villagers defecate in irrigated rice fields or rice field bunds. This habit causes soil and water to contaminated with worm eggs (Aryadnyani, 2016). Komatashi (2015) investigated the relationship between STH infection prevalence and parents 'socioeconomic conditions in the Kilasah Serang Timur village in Banten. In this study, the prevalence of helminthiasis was $96.6 \%$, and there was a significant relationship between STH infection and parents' socioeconomic conditions. Purwasih (2016) examined the relationship of Personal Hygiene to STH Infection in Children Aged 410 Years in the Kilasah Serang Timur Village, Banten. Based on the results of the study, there is a significant relationship between Personal Hygiene and STH Infection in Children Aged 4-10 Years. In this study, the prevalence of infection of Ascaris lumbricoides was $17.2 \%$, Trichuris trichiura $18.4 \%$, mixed of Ascaris lumbricoides, and Trichuris trichiura $56.3 \%$ and mixed of Trichuris trichiura and hookworm 1.1\%. The prevalence of STH infections in children aged 4-10 years in the village of East Serang, Banten, also studied by Maulina (2016) showed the prevalence of $97.7 \%$ infected with Ascaris lumbricoides and Trichuris trichiura. In Trichuris trichiura infection, $76.6 \%$ mild intensity, $22.1 \%$ moderate intensity, and $1.3 \%$ severe intensity.

The results of research by Komatashi (2015), Purwasih (2016), and Maulina (2016) show the prevalence of helminthiasis in the Kilasah Serang Timur Village in Banten, which is quite high. Based on the high level of helminthiasis, the author 
wishes to find out the level of hemoglobin in children in the Kilasah village of East Serang Banten, especially those infected by Trichuris trichiura.

\section{MATERIALS AND METHOD}

A sampling of research carried out in the village of Kilasah Serang Timur, Banten, and laboratory examinations carried out in the Medical Technology Laboratory of the Health Polytechnic, Ministry of Health Jakarta III. Subjects in this study were children aged 3-12 years. This study approved by the Health Research Ethics Commission of the Jakarta Health Polytechnic III. Ethics Approval Number: KEPK-PKKJ3 / 127 / III / 2018.

The number of research subjects participating in this study was 42 people. Subjects were taken venous blood for the examination of hemoglobin and feces for the examination of worm eggs. Examination of blood hemoglobin levels using the Medonic M-Series M32 device and examination of Trichuris trichiura eggs in feces using the Kato-Katz method. To find out a significant relationship between Trichuris trichiura infection with hemoglobin levels using a Spearman non-parametric test.

\section{RESULTS AND DISCUSSION}

Table 1. Average of Eggs Trichuris trichiura/Gram Feces and Hemoglobin Levels

\begin{tabular}{ccc}
\hline & $\begin{array}{c}\text { The Number of } \\
\text { T. trichiura Eggs } \\
(/ g r \text { feces })\end{array}$ & $\begin{array}{c}\mathrm{HB} \\
(\mathrm{gr} / \mathrm{dL})\end{array}$ \\
\hline Total & 75.255 & 521,8 \\
Average & $1.791,79$ & 12,42 \\
Max Value & 8.925 & 14.0 \\
Min Value & 100 & 10.2 \\
\hline
\end{tabular}

Table 2. Trichuris trichiura Infection Rate in Children in Kilasah Serang Timur Village, Banten in 2018

\begin{tabular}{ccc}
\hline $\begin{array}{c}\text { Worm Infection } \\
\text { Rate }\end{array}$ & $\begin{array}{c}\text { Frequency } \\
(\mathrm{n})\end{array}$ & $\begin{array}{c}\text { Percentage } \\
(\%)\end{array}$ \\
\hline Mild Levels & 23 & 54.76 \\
Moderate Levels & 19 & 45.24 \\
Total & 42 & 100 \\
\hline
\end{tabular}

Based on the results of trichuriasis examination on children's feces in the village of Kilasah, 24 children (55.8\%) obtained with mild levels and 19 children (44.2\%) with moderate levels.

Table 3. Hemoglobin Levels in Children in Kilasah Village, East Serang Banten in 2018

\begin{tabular}{ccc}
\hline Hemoglobin levels & $\begin{array}{c}\text { Frequency } \\
(\mathrm{n})\end{array}$ & $\begin{array}{c}\text { Percentage } \\
(\%)\end{array}$ \\
\hline Normal $(\geq 11.5 \mathrm{gr} / \mathrm{dL})$ & 36 & 85,71 \\
Low $(\leq 11.4 \mathrm{gr} / \mathrm{dL})$ & 6 & 14,29 \\
Total & 42 & 100 \\
\hline
\end{tabular}


Table 4. Normality Test

\begin{tabular}{cccc}
\hline & \multicolumn{3}{c}{ Shapiro-Wilk } \\
& Statistic & df & Sig. \\
\hline Hemoglobin Levels & 0.951 & 42 & 0.069 \\
The Number of $T$. trichiura Eggs & 0.715 & 42 & 0.000 \\
\hline
\end{tabular}

Based on the normality test, obtained a significance value $<0.05$, which means the data distribution is not normal. To test the correlation between Trichuris trichiura infection and hemoglobin levels, a Spearman non-parametric test performed.

Table 5. Spearman Correlation Test

\begin{tabular}{llc}
\hline & & The Number of T. trichiura \\
& & Eggs \\
\hline Hemoglobin Levels & Spearman Correlation & $-0.892^{* \times}$ \\
& Sig. (2-tailed) & 0.000 \\
& $N$ & 42 \\
\hline
\end{tabular}

Based on the Spearman Correlation Test obtained a significance value $<0.05$, which means there is a negative correlation between Trichuris trichiura infection with hemoglobin levels. A negative correlation means that the higher the infection rate, the lower the hemoglobin level. The average hemoglobin level was $12.42 \mathrm{gr} / \mathrm{dL}$ with the lowest hemoglobin level $10.2 \mathrm{gr} / \mathrm{dL}$, and the highest hemoglobin level was 14.0 $\mathrm{gr} / \mathrm{dL}$. Based on the results of the examination table of hemoglobin levels in children in the kilasah village obtained as many as 36 children (81.71\%) had normal hemoglobin levels and six children (14.29\%) with low hemoglobin levels. This is consistent with the results of research Basalamah et al. (2013) there was a tendency for children infected with worms to experience abnormal $\mathrm{Hb}$ levels. According to the research by Molla and Mamo (2018) on Soil-transmitted helminth infections, anemia and undernutrition among schools in Yirgacheffee, South Ethiopia shows the prevalence of STH infections by $54.0 \%$, anemia prevalence by $15.4 \%$ and prevalence of malnutrition by $28.9 \% \%$. Worm species found are Ascaris lumbricoides, hookworms, and Trichuris trichiura. According to Wijianingsih (2011), on the type of worm, Trichuris trichuria anemia can occur because this worm inserts his head into the intestinal mucosa until trauma occurs, which causes irritation and inflammation of the intestinal mucosa. At the place of attachment can cause bleeding, besides this worm sucks the blood of the host so that it can cause anemia.

The results of this study are in line with research conducted by Basalamah et al. (2013), Inayah et al. (2016), that there is a significant relationship between helminthiasis with hemoglobin levels in children. Children who infected with worms in a long period (chronic) will experience a decrease in hemoglobin levels. Quihui-Cota et al. (2010) examined Trichuriasis and low-iron status in schoolchildren from Northwest Mexico, the results of hemoglobin, hematocrit, RBC, and iron serum concentrations in children who were free of Trichuris trichiura were higher than those infected with Trichuris trichiura. Gyorkos et al. (2012) have examined the Re-Visiting Trichuris Trichiura Intensity Thresholds Based on Anemia during Pregnancy, and the result is that moderate infection in pregnant women is a significant risk factor for anemia in pregnant women. The intensity of Trichuris infection, which considered to 
cause or worsen anemia, is the intensity of 'severe' and 'moderate' Trichuris infection.

A limitation of this study is the limited number of respondents who participated. The advice that can be given based on this research is that efforts must be made from the local health office to increase knowledge about personal hygiene to villagers. Efforts can be made through health education to prevent worm infections and administration of mass worming every six months. It is also important to provide blood-boosting medication for residents who have anemia.

\section{CONCLUSION}

There is a significant relationship between the degree of Trichuris trichiura infection with hemoglobin levels in children in the village of Serang Timur Kilasah Banten.

\section{ACKNOWLEDGMENT}

The authors would like to thank all parties involved in this study.

\section{CONFLICT OF INTEREST}

There are no conflicts of interest in this study.

\section{REFERENCE}

Aryadnyani, N. P. (2016). Gambaran Perilaku yang Mendukung Siklus Hidup dan Tingkat Infeksi Soil Transmitted Helminths di Desa Kilasah Kecamatan Kasemen Serang Timur Banten. Prosiding Seminar Nasional Kesehatan 2016. Hasil-Hasil Penelitian. Poltekkes Kemenkes Jakarta III. ISBN: 978-602-71774-68.

Basalamah, M. F., Pateda, V., \& Rampengan, N. (2013). Hubungan Infeksi Soil Transmitted Helminth Dengan Kadar Hemobglobin Anak Sekolah Dasar Gmim Buha Manado. E-CliniC, 1-6. Retrieved from http://ejournal.unsrat.ac.id/index.php/eclinic/article/view/3601.

Chadijah, S., Sumolang, P. P. F., \& Veridiana, N. N. (2014). Hubungan Pengetahuan, Perilaku, Dan Sanitasi Lingkungan Dengan Angka Kecacingan Pada Anak Sekolah Dasar Di Kota Palu. Media Penelitian dan Pengembangan Kesehatan, 24(1), 50-56. Retrieved from http://ejournal.litbang.depkes.go.id/index.php/MPK/article/view/ 3487.

Dirjen PP dan PL. (2012). Pedoman Pengendalian Kecacingan. Jakarta: Kementerian Kesehatan RI.

Gyorkos, T. W. and Gilbert, N. L. (2014). Blood Drain: Soil-Transmitted Helminths and Anemia in Pregnant Women. Plos Neglected Tropical Diseases, 8(7), 7-8. DOI: 10.1371/journal.pntd.0002912.

Ibrahim, I. A. (2014). Status Kecacingan Soil Transmitted Helminth (Sth) Dalam Pemantauan Kejadian Anemia Pada Murid Sd Inpres Bakung Samata Kabupaten Gowa Tahun 2013. Jurnal Kesehatan, 7(1), 254-266. Retrieved from http://journal.uin-alauddin.ac.id/index.php/kesehatan/article/view/944.

Inayah, Z., Deo, A. D., \& Buntoro, I. F. (2016). Hubungan Infeksi Cacing Dengan Kadar Hemoglobin Pada Sd Inpres Ndona 4 Kecamatan Ndona Kota Ende, 99$106 . \quad$ Retrieved from http://www.vetpub.net/attachments/File/Prosiding2016Semnas4/11. pdf. 
Indriyati, L., Hairani, B., Fakhrizal, D. (2015). Kehilangan Nutrisi dan Darah serta Kerugian Biaya Akibat Kecacingan pada Anak Sekolah di SDN Manurung 1 Pagatan. Epidemiology and Zoonosis Journal. 5(3), 107-114.

Komatashi, B. T. (2015). Hubungan Prevalensi Infeksi Nematoda Usus Soil Transmitted Helminths (STH) dengan Kondisi Sosial Ekonomi Orang Tua di Desa Kilasah Serang Timur Banten. (Skripsi). Fakultas Biologi Universitas nasional, Jakarta.

Maulina, F., (2016). Prevalensi Infeksi Nematoda Usus Soil Transmitted Helminths Pada Anak Usia 4-10 Tahun di Desa Kilasah Serang Timur Banten Tahun 2016 $(\mathrm{KTI})$. Jurusan Analis Kesehatan Poltekkes Kemenkes Jakarta III, Jakarta.

Meru, R. C. A. (2006). Hubungan Kecacingan dengan Kejadian Anemia pada Anak Sekolah Dasar di Daerah Endemis Malaria.

Molla, E., and Mamo, H. (2018). Soil-transmitted helminth infections, anemia, and undernutrition among schoolchildren in Yirgacheffee, South. BMC Research Notes. BioMed Central, 1-7. DOI: 10.1186/s13104-018-3679-9.

Purwasih, A., N., A. (2016). Hubungan Personal Hygiene Terhadap Infeksi Nematoda Usus Soil-Transmitted Helminths Pada Anak Usia 4-10 Tahun di Desa Kilasah Serang Timur Banten

Quihui-Cota, L. et al. (2010). Trichuriasis and Low-Iron Status in Schoolchildren from Northwest Mexico. European Journal of Clinical Nutrition, 64, 1108-1115. DOI: 10.1038/ejcn.2010.146.

Rusmanto, D., \& Mukono, J. (2012). Hubungan Personal Higyene Siswa Sekolah Dasar dengan Kejadian Kecacingan. The Indonesian Journal of Public Health, 8(3), 105-111. Retrieved from http://journal.unair.ac.id/downloadfull/PH5960Obd16e4447fullabstract.pdf.

Semuel, S., Sumarni, S., \& Soeyoko. (2015). Analisis Model Faktor Risiko Yang Mempengaruhi Infeksi Kecacingan Yang Ditularkan Melalui Tanah Pada Siswa Sekolah Dasar Di Distrik Arso Kabupaten Keerom, Papua. Media Penelitian dan Pengembangan Kesehatan, 25(1), 1-14. Retrieved from http://ejournal.litbang.depkes.go.id/index.php/MPK/article/view/4091.

Syahrir, S., \& Aswadi. (2016). Faktor yang Berhubungan dengan Kejadian Kecacingan pada Siswa SDN Inpres 1 Wora Kecamatan Wera Kabupaten Bima, 2(1), 41-48. Retrieved from http://journal.uinalauddin.ac.id/index.php/higiene/article/view/ 1805.

Umar, Z. (2008). Perilaku cuci tangan sebelum makan dan kecacingan pada murid SD di kabupaten pesisir selatan Sumatera Barat. Jurnal Kesehatan Masyarakat Nasional, 2(6), 249-254. Retrieved from jurnalkesmas.ui.ac.id/index.php/kesmas/article/view/244\%5Cn.

Wijianingsih, S. Y. (2011). Hubungan Antara Infeksi Kecacingan dengan Anemia dan Status Gizi pada Siswa SDN Purwosari 1 Kecamatan Tamban Kabupaten Barito Kuala Tahun 2010.

World Health Organization. (2017). Guideline: Preventative chemotherapy to control soil-transmitted helminth infections in at-risk population groups. 